\title{
The Effect of Technology Infrastructure in Customer Relationship Management on Profit Increases with Customer Relationship Management (CRM) Process Mediation: An Empirical Study of the Indonesian Banking Industry
}

\author{
Tami Sitorus ${ }^{1}$, Machmudin Eka Prasetya ${ }^{1^{*}}$ \\ ${ }^{1}$ Faculty of Economics and Business, Universitas Indonesia, Jakarta Pusat 10430, Indonesia \\ *machmudin.prasetya@yahoo.com
}

\begin{abstract}
This research studies the effect of technology infrastructure in CRM on profit increases with CRM process mediation. It was conducted on conventional banks listed on the Financial Service Authority (OJK), whose Head Office is located on DKI Jakarta, excluding foreign banks and Islamic banks. The study sample consisted of 30 banks which were willing to return the research questionnaire. In testing the hypothesis on path analysis, the data was processed using LISREL 9, and its validity and reliability tested using SPSS v.22. The results found that the technology infrastructure in CRM significantly affects the CRM process, but that it has no effect on CRM on the profit increases. On the other hand, the CRM process can increase profits significantly, so it can mediate the effect of technology infrastructure in CRM on these increases. The research shows that the indicators of the CRM process and technology infrastructure in CRM are relatively high, but that profit growth is not determined by the technology infrastructure in CRM directly, and that the CRM process should mediate the effect on some banks that were part of the research sample.
\end{abstract}

Keywords: Customer Relationship Management (CRM), Technology Infrastructure in CRM, CRM Process, Profit Increases.

\section{INTRODUCTION}

Business strategy will lead to success if it is developed after the organization learns about its customers' behavioral patterns ${ }^{1}$. In a competitive economic environment with a variety of financial challenges, to enhance competitive advantage between companies success depends on the ability of the company to achieve customer satisfaction ${ }^{2}$. A customer satisfaction orientation emphasizes the need for development in building relationships with customers, with the goal of service and customer satisfaction ${ }^{3}$.

(CRM) will increase loyalty and achieve sales increases ${ }^{4}$. CRM helps companies to add value that they absorb from customers, especially when they have identified specific customer needs ${ }^{5}$. Companies may therefore consider investing in the implementation of CRM strategy each period ${ }^{6}$.

Santouridis and Tsachtani examined the significant effect of the use of technology for CRM or CRM technology infrastructure on the CRM process ${ }^{7}$. Their study was conducted on the Greek banking industry. The CRM process is a customer-oriented one, starting from the process initiation, acquisition, regain maintenance, retention, expansion, and exit. The process will affect the company's economic performance ${ }^{8}$. One of the measures of a company's economic performance is increased profits?.

\section{LITERATURE REVIEW AND HYPOTHESIS DEVELOPMENT}

Customer Relationship Management (CRM) is a practice for analyzing marketing databases and utilizing communications technology to estimate corporate practices and methods that maximize customer lifetime ${ }^{10}$. While interaction between producer and customers are demonstrated by the services available on a timely basis, this interaction should implement methods that fit customer needs and wants ${ }^{1}$. CRM can also be defined as a process which maximizes customer value through ongoing marketing activities, which create customer knowledge built on the collection and management of customer information, with a history of contact with them ${ }^{11}$.

CRM technology infrastructure should pay attention to the availability of software, hardware systems, technical support, data completeness, and data availability across channels ${ }^{7}$. When implemented properly, it will create 
benefits for employees ${ }^{2}$. Information about the customer will increase considering its customer relationship periods, while the effectiveness of the CRM system is based on the quality and quantity of customer data input ${ }^{12}$. Therefore, in this study the first proposed hypothesis is as follows:

\section{H1: CRM technology infrastructure positively affects CRM processes}

The longer someone is a customer of a company, the more likely it is that they will increase their purchases ${ }^{13}$. Customer satisfaction can help increase customer life, so companies need to improve their competitive advantage in terms of customer ${ }^{2}$. Companies that are committed to CRM activities will implement them well, thereby ultimately impacting on increases in corporate profits ${ }^{5}$. Good CRM implementation contributes to the profitability of a company, so CRM analysis of the CRM process, which provides information about customers and consequently provides benefits to the company, will support company economic performance ${ }^{9}$. This research thus proposes a second hypothesis:

H2: The CRM process has a positive effect on increased profits

CRM is not just information technology, but also a business methodology that affects the goals, plans, work, and processes of the company ${ }^{14}$. Computer technologies such as computer-assisted manufacturing design, flexible manufacturing systems, just-in-time production databases, data warehouses, data mining, and CRM software, help companies to provide effective customization with high quality and low $\operatorname{cost}^{15}$.

H3: CRM technology infrastructure has a positive effect on increased profits

Based on the development of hypotheses $\mathrm{H} 1$ and $\mathrm{H} 2$, it can be perceived that there is an effect of the mediation of the CRM process variables in the impact of CRM technology infrastructure on profit increases. The effect of such mediation as indirect effect can be shown when conducting hypothesis testing using the LISREL 9 application. The effect of mediation is seen from the EF option in the application. This option is an output display showing the composition of the effect of both direct and indirect influences ${ }^{16}$. This can be reformulated in the following hypothesis:

H4: The CRM process mediates the positive impact of CRM technology infrastructure on profit increases

\section{RESEARCH METHOD}

The data used in this study is both primary and secondary data. Primary data collection is made on the CRM technology infrastructure and CRM process variables, while the secondary data collection was made on variable profit increase. The questionnaire contains questions for each variable dimension.

The populations in the study are all bank in Indonesia; only companies located in Indonesia are included. There are several reasons why the banking sector was selected as a research population. First, banks need a CRM system to support applications used for operational activities, such as the internet, mobile banking, and the matching of bank products to customer needs ${ }^{11}$. Second, the financial industry, particularly in the banking sector, provides very precise data for companies and other industrial sectors ${ }^{15}$. Third, the banking industry is an excellent role model for making business offerings through customer relationships, in which consumers spend considerable time online accessing their bank accounts, for example to pay bills electronically ${ }^{17}$. In addition, the banking sector in Indonesia is required to publish companies' financial information to the Financial Service Authority (OJK).

This study uses a sample of the banking industry that acts as conventional banks formed as corporations (not Union Cooperative firms or Regional Development Banks), whose head offices are in Jakarta Capital City province.

Based on the hypothesis development, in hypothesis testing the path analysis model is appropriate for use. However, before determining the regression equation model, it is necessary to test the $t$ value. The equations set for the path analysis regression model are as follows:

$$
\begin{aligned}
& \mathrm{CRMP}(\mathrm{IT})=\beta \mathrm{IT}+\mathrm{e} 1 \\
& \mathrm{RG}(\mathrm{IT}, \mathrm{CRMP})=\beta \mathrm{IT}+\beta \mathrm{CRMP}+\mathrm{e} 2
\end{aligned}
$$

Description:

IT

: CRM technology infrastructure 


$\begin{array}{ll}\text { CRMP } & \text { : CRM process } \\ \text { PROFIT } & \text { : Profit increase } \\ \alpha & : \text { Constant } \\ \beta & : \text { Coefficient } \\ \text { e } & : \text { error }\end{array}$

Table.1. Sampling Process.

\begin{tabular}{lr}
\hline Description & Amount \\
\hline Population (Banks listed in OJK) & $\mathbf{1 9 2 1}$ \\
Not selected in sampling & \\
- Rural Banks & 1636 \\
- Rural Banks Sharia & 165 \\
- Regional Development Banks & 27 \\
- Branch Office of Foreign Banks & 10 \\
- Sharia Banks & 11 \\
Selected in sampling & $\mathbf{7 2}$ \\
Head office not lcated in Jakarta & 15 \\
Research Sample & $\mathbf{5 7}$ \\
\hline
\end{tabular}

CRM technology infrastructure variables are independent variables. Later, the CRM technology infrastructure variable is mentioned as IT. The CRM process variable is an intervening variable. Later, this variable is mentioned as CRMP. These two variables are measured by using questionnaires addressed to respondents working as bank employees in marketing departments who are in charge of handling customer relationships.

The dependent variable in this research is increased profit. As this is a dependent variable, it is tested twice, to establish whether is affected by IT with CRMP mediation or is directly affected by IT. Later, this variable is mentioned as PROFIT.

Confirmatory Factor Analysis is used to measure the validity and reliability of a variable size. The measurement model fit to be able to confirm whether the variable is indeed a measure or reflects a latent variable ${ }^{16}$. The measurement technique is performed for the reliability test using variance extracted and construct reliability ${ }^{16}$. This technique was developed by Fornel and Larker in $1981^{16}$.

For this study, the testing used is path analysis, which is employed for research models that test the effect of intervening or mediation variables ${ }^{18}$. In this research, the track diagram used is the structural model. To obtain the model and estimate, the application used is LISREL 9.

\section{RESULTS AND DISCUSSIONS}

Only 30 banks were willing to respond and return the questionnaires. To ascertain these characteristics assessment based on interval class can be used. The variables measured by the questionnaire can calculate the intervals according to the Likert scale in the questionnaire, and each interval class is divided into the score range category (Lind et al., 2013). The Likert scale used in the questions is on a scale from 1 to 5. From the calculation 0.8 was obtained.

\begin{tabular}{ll}
\multicolumn{2}{l}{ Table.2. Sample Characteristics Grouping. } \\
\hline Interval Class & Characteristic \\
\hline $1.0-1.8$ & Bad \\
$1.9-2.6$ & Fair \\
$2.7-3.4$ & Moderate \\
$3.4-4.2$ & Good \\
$4.3-5.0$ & Very Good \\
\hline
\end{tabular}

The sample has a technology infrastructure implementation that supports the company's CRM activities well, reaching a mean score of 3.83 and a variant at 0.02 . The company already owns and utilizes the software well.

The analysis with descriptive statistics for CRMP is also the same in the case of IT. Overall, CRMP has been well implemented, achieving an average value of 3.93 and a variant of 0.08 .

Profit increase is measured by its percentage of increase or decrease. The profit increase of banking firms is divided into two groups: significant and insignificant increases. An increase of $11.5 \%$ or more is a significant profit increase, while that which does not reach $11.5 \%$ is not a significant increase or even a decrease in profits. The mean score that describes the characteristics of the sample was $27.33 \%$. This means that the sample shows a significant profit increase. 
Table.3. Descriptive Statistics for IT.

\begin{tabular}{|c|c|c|c|}
\hline Item & Variable & Mean & $\begin{array}{l}\text { Deviation } \\
\text { Standard }\end{array}$ \\
\hline IT 1 & Database & 3,7667 & 0,93526 \\
\hline IT 2 & Software & 3,9333 & 0,90719 \\
\hline IT 3 & Software & 4,0333 & 0,71840 \\
\hline IT 4 & $\begin{array}{l}\text { Hardware } \\
\text { Integrated }\end{array}$ & 3,7333 & 0,82768 \\
\hline IT 5 & $\begin{array}{l}\text { information } \\
\text { systems }\end{array}$ & 3,8000 & 0,71438 \\
\hline IT 6 & $\begin{array}{l}\text { Integrated } \\
\text { information } \\
\text { systems }\end{array}$ & 3,9000 & 0,75886 \\
\hline IT 7 & Technical support & 3,9333 & 0,78492 \\
\hline IT 8 & $\begin{array}{l}\text { Technical } \\
\text { supports }\end{array}$ & 3,5667 & 0,93526 \\
\hline
\end{tabular}

Table.4. Descriptive Statistics for CRMP.

\begin{tabular}{clccc}
\hline $\begin{array}{c}\text { Items } \\
\text { in total }\end{array}$ & $\begin{array}{c}\text { Dimension } \\
\text { of variables }\end{array}$ & Mean & Maximum & Minimum \\
\hline 8 & Initiation & 3,92 & 5 & 1 \\
5 & Acquisition & 3,58 & 5 & 1 \\
4 & Regain & 3,92 & 5 & 2 \\
4 & Maintenance & 4,03 & 5 & 2 \\
8 & Retention & 4,17 & 5 & 1 \\
5 & Expansion & 4,16 & 5 & 1 \\
4 & Exit & 3,40 & 5 & 1 \\
\hline
\end{tabular}

Table.5. Descriptive Statistics for Profit Increase.

\begin{tabular}{lr}
\hline Mean & $27,33 \%$ \\
Median & $11,50 \%$ \\
Mode & $-95 \%$ \\
Maximum & $343 \%$ \\
Minimum & $-140 \%$ \\
\hline
\end{tabular}

The reliability and validity test for CRMP obtained 31 out of 38 items of questions that passed the test. The CRMP items initiation and retention were tested twice to obtain items to measure these dimensions, and acquisition was tested three times; only 31 items remained valid.

The results of the IT variance extracted calculations showed a value of 0.571 , while the calculation of construct reliability was 0.914 . Therefore, the eight items that constructing IT passed the reliability test

Based on the results of the validity test, the question items that became constructs of the CRMP variable consisted of 31 items that passed the validity test.

Table.6. Variance Extracted and Construct Reliability for the CRM process

\begin{tabular}{lcc}
\hline Dimension & $\begin{array}{c}\text { Variance } \\
\text { Extracted }\end{array}$ & $\begin{array}{c}\text { Construct } \\
\text { Reliability }\end{array}$ \\
\hline Initiation & 0,534 & 0,855 \\
Acquisition & 0,762 & 0,865 \\
Regain & 0,689 & 0,897 \\
Maintenance & 0,688 & 0,868 \\
Retention & 0,504 & 0,875 \\
Expansion & 0,544 & 0,854 \\
Exit & 0,495 & 0,793 \\
\hline
\end{tabular}

According to the goodness of fit score, hypothesis testing considers the estimated path diagram that is based on the t-value and standardized solution. Based on the t-value, there is a significant effect in hypothesis 1 and hypothesis 2 , so both hypotheses are accepted, while hypothesis 3 shows that the absolute t-value is less than 1.96 , which is not supported in this study. The path diagram can also show the coefficient of the standardized solution. The model is shown in the Figure 2. 


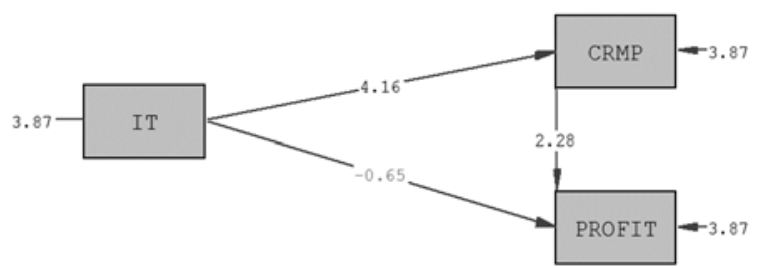

Fig.1. Hypothesis testing Structural Model with t-value.

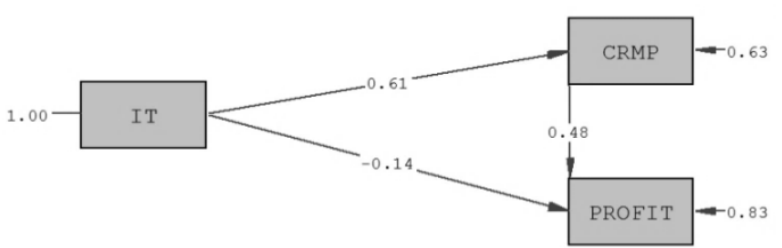

Fig.2. Hypothesis testing Structural Model with Coefficient of Standardized Solution.

Hypothesis 1 concerns the effect of IT on CRMP. From this test, a t-value for the IT variable on CRMP equal to 4.16 was obtained, which is greater than 1.96. The test has got result that is significant effect. The standardized solution score is 0.61 , while the coefficient for the CRMP is 0.63 . Therefore, CRM technology infrastructure has a significant positive effect on the CRM process. Hypothesis 2 concerns the effect of the intervening variable CRMP on PROFIT. In this test, it obtained a t-value of 2.28. The standardized solution scored 0.48 , while the coefficient for PROFIT was 0.83 . Therefore, the CRM process has a significant positive effect on profit increase.

Hypothesis 3 concerns the direct effect of IT on PROFIT. According to the t-value, which is smaller than 1.96, it can be seen that there is no effect of IT on PROFIT. This hypothesis cannot therefore be supported in this study. The t-value of IT to PROFIT reaches -0.65 , or an absolute value of 0.65 . The standardized solution obtained a value of -0.14 .

By supporting $\mathrm{H} 1$ and $\mathrm{H} 2$, the CRM process is considered capable of mediating the impact of CRM technology infrastructure on profit increases. This is shown in the indirect effect of 0.294 in the EF option. The t-value is 2.00. The direct effect of IT on CRMP is 0.561 , while the direct effect of the CRM process on increased profit is 0.524 .

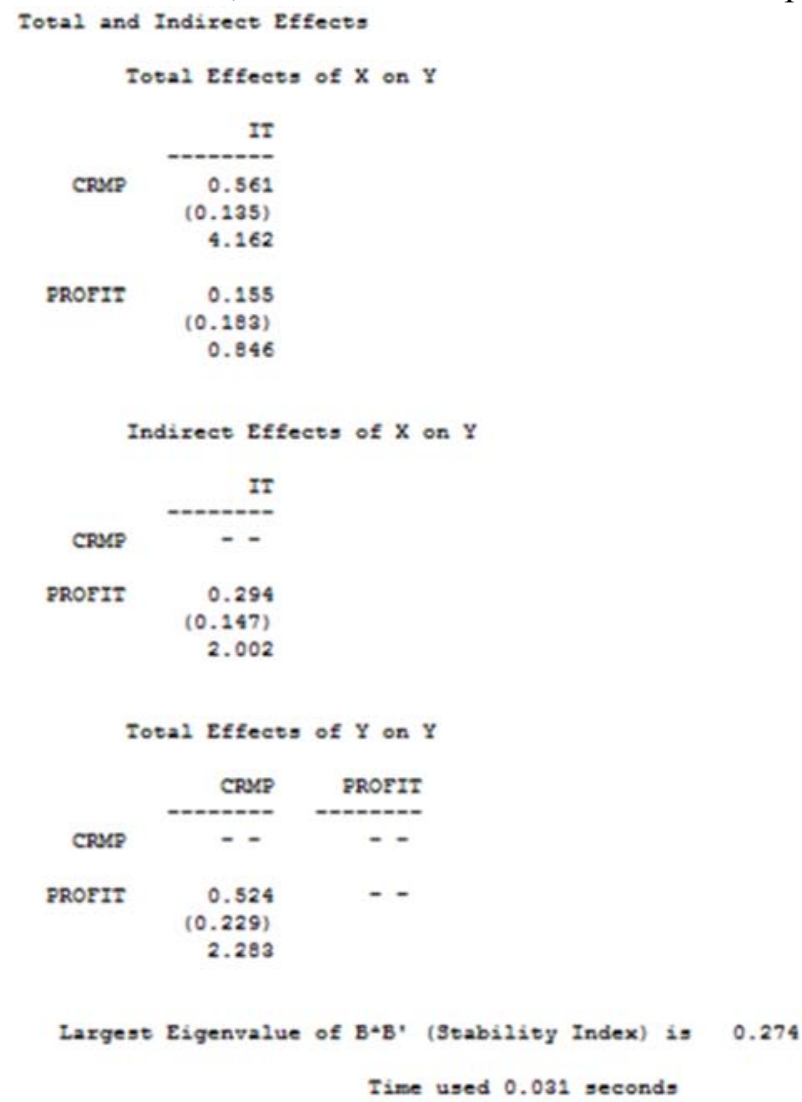

Fig.3. Indirect and Direct Effect with EF Option. 
The coefficient of IT that affects CRMP is 0.5612 , with the significance level of the $\mathrm{p}$ value 0.0004 , which is lower than 0.05 . This is in line with the theory developed by Bolton and Tarasi, which states that the CRM process begins with the fundamental assumption that it is better to start, maintain, and build relationships, supported and developed by the organization's specific capabilities, which is the use of database intelligence and information technology ${ }^{19}$. Likewise, Kumar and Reinartz suggest that information technology makes processes more efficient, transforms processes and services and supports a whole new process, especially during online activities ${ }^{20}$.

The coefficient of CRMP to PROFIT is 0.5235 , with a significance level of the $p$ value of 0.0393 , lower than 0.05. This supports the theory developed by Payne that the CRM process is a business approach that aims to create, develop, and improve customer relationships that have been targeted in order to increase customer value, corporate profitability, and maximize shareholder value ${ }^{21}$. The results of this study support the theories developed by Shainesh and Sheth, in which the cost allocated to the CRM process by acquisition of the customer will turn back points into profits along with the increasing loyalty of customers. Longer customer lives are more likely to increase the level of their purchases ${ }^{13}$. This study also supports the results of research conducted by Kamakura et al. ${ }^{22}$. The results prove that the input data in the CRM process also helps companies to analyze the profitability of customers so that it can design strategies to improve customer loyalty.

This contradicts the theory developed by Bolton and Tarasi, that CRM unites the potential strategies with information technology to create profitability and long-term relationships with customers and other key stakeholders $^{19}$. It can also make the process more efficient, transform processes and services, and provide complete support for new processes, especially during online activities ${ }^{9}$. Likewise, the theory developed by Peppers and Rogers in which technologies support companies to customize their products and services in large quantities, delivering products or services uniquely to customers, in response to feedback and specifications ${ }^{17}$. However, the results of this study are supported by Sin et al ${ }^{15}$. CRM technology infrastructure does not greatly affect corporate financial performance; instead, it will have a marked effect on marketing performance.

\section{CONCLUSIONS}

This study examines the relationship between CRM technology infrastructure and increased profit, with the mediation of the CRM process. The results show that the infrastructure has a significant effect on these increases with CRM process mediation. CRM technology infrastructure has a significant effect on the CRM process, and this process has a significant effect on profit increases. But directly, CRM technology infrastructure does not have a significant effect on profit increases. Furthermore, based on the analysis of the results with a $95 \%$ confidence level, this study concludes that: (1) with the availability of adequate technology infrastructure to support CRM activities, the CRM process will be well implemented; (2) as the CRM process improves, it will have an effect on increases in current year profits; (3) adequate technology infrastructure in CRM activities does not directly affect increases in current year profits; and (4) the CRM process is able to mediate the impact of CRM technology infrastructure on profit increases.

After completing the research, the limitations in this study are: (1) the research sample is small as the number of questionnaires returned to be processed only numbered 30; (2) it only conducts technology infrastructure that supports CRM activities with regard to companies' economic performance, while there are indications of others that may affect economic performance; (3) empirical studies were conducted only on the banking sector industry, so the type of CRM activities can only describe the conditions and behavior of banking sector customers; and (4) the results of the data collection for non-metric measurement are based on the assessment of employees, who were the respondents. To obtain a more comprehensive overview of the implementation of corporate CRM activities, subsequent research should use explorative methods. Finally, to ascertain in more detail the impact of CRM activity on company performance, the two-year period is too short.

\section{REFERENCES}

[1] A. Chaudhry, CRM: making it simple for the banking industry, Cary: SAS Institute Inc., SUGI, 29 (2004) 180-29.

[2] A. G. Moreno, N. Lockett, and V. G. Morales. Paving the way for CRM success: The mediating role of knowledge management and organizational commitment. Information \& Management, 51 (2014) 1031-1042.

[3] C. J. Stefanou, J. Constantinos, C. Sarmaniotis, and A. Stafyla. CRM and customer-centric knowledge management: an empirical research, Business Process Management Journal, 9 (2003) 617-634.

[4] J.Whitten and L. D. Bentley. System analysis and design methods 7th edition, Harlow: Pearson Education Limited, McGraw-Hill, New York, (2008).

[5] A. Krasnikov, S. Jayachandran, and V. Kumar. The impact of customer relationship management implementation on cost and profit efficiencies: evidence from the U.S. commercial banking industry, Journal of Marketing, 6 (2009) 61-76.

[6] S. H. Kim and T. Mukhopadhyay. Determining optimal CRM implementation strategies, Information Systems Research, 22 (2011) 624-639.

[7] I. Santouridis and E. Tsachtani. Investigating the impact of CRM resources on CRM processes: a customer life-cycle based approach in 
the case of a Greek bank, Procedia Economics and Finance, 19 (2015) 304-313.

[8] M. E. Kordy. The impact of CRM capability dimensions on organizational performance, European Journal of Business and Social Sciences, 2 (2014) 128-146.

[9] J. S. Chen and R. K. H. Ching. An empirical study of the impact of it intensity and organizational absorptive capacity on customer relationship management performance. Journal of Global Information Management, 12 (2002) 333-343.

[10] W. Reinartz, M. Krafft, and W. D. Hoyer. The customer relationship management process: its measurement and impact on performance Journal of Marketing Research, 41 (2004) 293-305.

[11] R. Barran, C. Zerres, and M. Zerres. Customer Relationship Management, (2008).

[12] J. U. Becker, G. Greve, and S. Albers. The impact of technological and organizational implementation of CRM on customer acquisition, maintenance, and retention, International Journal of Research in Marketing, 26 (2009) 207-215.

[13] G. Shainesh and J. Sheth. Customer Relationship Management, Trinity Press, New Delhi, (2014).

[14] A. M. Lech. Effects of IT use in improving customer service logistic processes, Procedia Computer Science, 61 (2015) 961-970.

[15] L. Y. M Sin, A. C. B. Tse, and F. H. K. Yim CRM: conceptualization and scale development, European Journal of Marketing, 39 (2004) 1264-1290

[16] S. H. Wijanto. Metode penelitian menggunakan structural equation modeling dengan LISREL 9. Lembaga Penerbit Fakultas Ekonomi Universitas Indonesia, Jakarta, (2015).

[17] D. Peppers and M. Rogers. Customer Relationship Management, Willey, New Jersey, (2004).

[18] I. Ghozali. Aplikasi analisis multivariate dengan program SPSS. Badan Penerbit Universitas Diponegoro, Semarang, (2002).

[19] R. Bolton and C. O. Tarasi. Managing customer relationships. Review of Marketing Research, 3 (2007) 3-38.

[20] V.Kumar and W. Reinartz. Customer Relationship Management 2nd edition, Springer-Verlag, Berlin, (2012).

[21] A. Payne. Handbook of CRM: achieving excellence in customer management. Butterworth-Heinemann, Oxford, (2005).

[22] W. Kamakura, C. F. Mela, A. Ansari, A. Bodapatti, P. Fader, R. Iyengar, P. Naik, S. Nelsin, B. Sun, P. C. Verhoef, M. Wedel, and R. Wilcox. Choice models and Customer Relationship Management, Marketing Letters, 16 (2005) 279-291. 